Stanisław Prutis ${ }^{1}$

\title{
Instrumenty planowania przestrzennego $w$ rolnictwie (założenia modelowe a rzeczywistość)
}

\section{Planowanie przestrzenne w badaniach Profesora Waleriana Pańki}

W dorobku naukowym Profesora Waleriana Pańki motyw przewodni stanowią relacje pomiędzy własnością gruntową a planowaniem przestrzennym. Relacje pomiędzy tymi kategoriami prawnymi leżały w głównym nurcie zainteresowań badawczych Profesora, czego dowodem jest rozprawa habilitacyjna na temat: „Własność gruntowa w planowej gospodarce przestrzennej. Studium prawne".

Zdaniem Autora studium, wykonywanie własności gruntowej w sferze korzystania wymaga istnienia samej przestrzeni produkcyjnej i trwałego uzbrojenia tej przestrzeni (przede wszystkim w zabudowę mieszkalną i gospodarczą) oraz właściwej organizacji obszarowej i użytkowej stworzonego gospodarstwa. Stąd też w sferze korzystania z gruntu planowanie przestrzenne powinno realizować lub współrealizować z innymi środkami organizacyjno-prawnymi gospodarki przestrzennej trzy zadania:

A. Chronić zasoby gruntowe przed ich przeznaczeniem na cele nierolnicze i przed jakościową ich degradacją.

B. Organizować tereny budowlane i zabudowę, wiążąc je z potrzebami produkcji rolnej.

C. Kształtować sam sposób zagospodarowania istniejącego rolniczego zasobu gruntowego, a zwłaszcza jego strukturę obszarową i użytkową. ${ }^{3}$

Pomimo zmiany ustroju politycznego i gospodarczego w ostatnich dwudziestu latach podstawowe zadania planowania przestrzennego w sferze korzystania z rolnej przestrzeni produkcyjnej nie uległy zasadniczej zmianie. Zmieniły się natomiast, co oczywiste, instrumenty i mechanizmy prawne planowania przestrzennego w ogólności, w tym także stosownie w zagospodarowaniu przestrzeni rolniczej.

Uniwersytet w Białymstoku.

Opublikowana w cyklu prac naukowych Uniwersytetu Śląskiego, Katowice 1978.

Ibidem, s. 98 i 99. 
Sytuacja ta stwarza dobrą okazję do porównania systemów planowania przestrzennego: stworzonego w ramach socjalistycznej gospodarki planowej końca lat 70-tych ubiegłego wieku oraz obowiązującego i stworzonego w gospodarce rynkowej w oparciu o ustawę o planowaniu i zagospodarowaniu przestrzennym z dnia 27 marca 2003 r. ${ }^{4}$ Tak się bowiem składa, iż pomimo diametralnych różnic pomiędzy obydwoma systemami gospodarczymi, w instrumentach planowania przestrzennego obu okresów zachodzi wiele podobieństw.

Porównań dokonać możemy nie tylko w sferze normatywnego modelu organizacyjno-prawnego planowania przestrzennego, lecz także w świetle praktycznych doświadczeń stosowania mechanizmów planowania. Profesorowi Walerianowi Pańce zawdzięczamy bowiem nie tylko opracowanie ww. studium prawnego, lecz także przeprowadzenie badań empirycznych w tym zakresie. W latach 1973-74 w ośmiu ówczesnych powiatach przeprowadzone zostały, pod kierunkiem Prof. Andrzeja Stelmachowskiego, badania w temacie: „Wpływ instrumentów prawnych na przestrzenną strukturę rolnictwa w Polsce", w ramach którego Walerian Pańko opracował „Planowanie przestrzenne, ochrona gruntów rolnych oraz rejonizacja rolnicza jako środki kształtowania produkcyjnej przestrzeni rolniczej". ${ }^{5}$

Doświadczenia empiryczne pokazały, że nie należy idealizować planowania przestrzennego, ponieważ pomiędzy normatywnym modelem organizacyjno-prawnym planowania przestrzennego, a rzeczywistością gospodarczą zachodziły istotne rozbieżności co do stopnia realizacji zadań stawianych przed planowaniem przestrzennym w latach 70-tych i 80-tych XX wieku.

Warto przypomnieć krytyczną ocenę rzeczywistości planistycznej dokonaną wówczas przez Waleriana Pańkę, zaznaczając, iż sformułowania użyte w publikacji musiały mieć także na uwadze działającą wówczas cenzurę. W podsumowaniu swojego opracowania W. Pańko zawarł m.in. następujące konstatacje:

1. W planowaniu przestrzennym obszarów wiejskich właściwe miejsce winno znaleźć planowanie regionalne, obejmujące nie tylko tereny wielkich inwestycji rolnych (np. terenów melioracyjnych) ale i całe regiony przyrodniczo-ekonomiczne pokrywające się często z obecnymi granicami województw. Plany te powinny być prostą konsekwencją planów rozwoju społeczno-gospodarczego województw. Planowanie regionalne nie może być jednak wyrazem lokalnych interesów województw, ale elementem ogólnokrajowych założeń przestrzennych gospodarki żywnościowej i rolnictwa.

$4 \quad$ Tekst jedn. Dz.U. z 2012 r. poz. 647

5 Wyniki badań zostały opublikowane w pracy zbiorowej: „Wpływ instrumentów prawnych na przestrzenną strukturę rolnictwa w Polsce”, pod red. A. Stelmachowskiego, Warszawa 1977. W ramach tego tematu prowadziłem badania w podtemacie: „Wpływ rozwiązań prawnych na przestrzenne rozmieszczenie inwestycji melioracyjnych i wodociągowych". W skład zespołu badawczego wchodzili również: Paweł Czelhawski, Małgorzata Korzycka oraz Bohdan Zdzieniecki. 
2. „Uproszczone plany” gmin nie mogą zastąpić „,pełnych” planów miejscowych. Konieczna bowiem jest planowa regulacja nie tylko zabudowy wsi, ale i sporządzanie planów urządzeniowo-rolnych, kooperacji między sektorami, produkcyjnej i własnościowej koncentracji ziemi, programowanie zmian struktury użytków rolnych i struktury upraw.

3. Nastąpić winna radykalna zmiana w metodach współpracy organów planowania gospodarczego i przestrzennego. Obowiązkiem organów planowania gospodarczego powinno być nie tylko przekazywanie informacji, lecz także przeprowadzenie głębokich analiz prognostycznych; nie schematyczne opracowania zadań według odgórnych wskaźników, ale wspólna z urbanistami refleksja nad społecznogospodarczym rozwojem danego organizmu przestrzenno-administracyjnego. Najlepszym chyba rozwiązaniem byłaby instytucjonalna i kadrowa integracja planowania gospodarczego i przestrzennego, która też z wolna następuje.

4. Trudna jest ocena wpływu wprowadzenia gmin na gospodarkę przestrzenną w rolnictwie. Gmina może gwarantować ochronę zasobów gruntowych przed nadmiernym wzrostem i nieracjonalnością lokalizacji terenów budowlanych, nie chroni jednak gruntów rolnych przed ekspansywnością przestrzenną przemysłu.

5. Ochrona gruntów rolnych winna się wyrażać w rzeczywistym i wieloletnim programowaniu gospodarki gruntami rolnymi. Przeznaczenie gruntów rolnych na cele nierolne musi znajdować pełne uzasadnienie w planach zagospodarowania przestrzennego. Obecny stan tych planów w odniesieniu do ich aktualizacji i stabilności wskazuje na konieczność szerszego przestrzegania trybu zmian i aktualizacji planistycznych w omawianym zakresie. Pełna dyscyplina opracowywania i wykonania zadań planowych winna objąć wszystkie podmioty działające w przestrzeni objętej planem, niezależnie od charakteru podporządkowania tych podmiotów w stosunku do organów planowania. Regiony intensywnego rozwoju gospodarki rolnej nie mogą stanowić tylko organizmu chronionego, winien im służyć system preferencji zapewniających rozwój tych regionów.

6. Prawne środki rejonizacji rolnej winny realizować ustalenia rejonizacji przyrodniczo-ekonomicznej, uwzględniając przede wszystkim perspektywę rozwoju rolnictwa. Należałoby stworzyć organizacyjne środki kształtowania właściwej struktury użytków, koncentracji i specjalizacji produkcji rolnej w danym rejonie. ${ }^{6}$

Informacje na temat planowania przestrzennego uzupełnić trzeba o stosowne wówczas mechanizmy planowania przestrzennego w wiejskich jednostkach osad- 
niczych. W zdecydowanej większości badanych jednostek nie było ogólnych lub szczegółowych planów zagospodarowania przestrzennego. Plany te były zastępowane przez swoiste surogaty. Początkowo były to plany wyznaczania terenów budowlanych, które ustalono na podstawie ustawy o terenach budowlanych na obszarach wsi (tzw. WTB), z tym że ograniczały się jedynie do zarysowania linii dzielących tereny budowlane od pozostałych trenów wsi i linii rozgraniczających tereny o różnym przeznaczeniu, ${ }^{7}$ służąc tylko organizacji terenów budowlanych na wsi, a nie organizacji całej produkcyjnej przestrzeni rolnej. Po reformie gminnej 1972 r. dla gmin nieposiadających dotychczas miejscowych planów ogólnych opracowywano „uproszczone plany zagospodarowania przestrzennego gmin”, mające - z założenia - funkcje ograniczone do: a) ukierunkowania planowej zabudowy wsi w dostosowaniu do aktualnego podziału terytorialnego, b) zapewnienia ochrony gruntów rolnych, c) opanowania żywiołowości w budownictwie na wsi. ${ }^{8}$ Według oceny W. Pańki uproszczone plany były planami o zdecydowanym profilu urbanistycznym, nie rozwiązywały jednak problemu organizacji produkcyjnej przestrzeni rolniczej. Uproszczone plany nie mieściły się $\mathrm{w}$ istocie w ustawowej strukturze planów zarówno ze względu na ograniczoną zawartość tematyczną, jak i na tryb opracowania i zatwierdzania. ${ }^{9}$

Dla dopełnienia obrazu planowania przestrzennego lat 70-tych minionego wieku pozwolę sobie przytoczyć moją ocenę poczynioną w toku badań nad przestrzennym rozmieszczeniem inwestycji melioracyjnych i wodociągowych. Otóż zaskakującym spostrzeżeniem było stwierdzenie neutralnej roli instrumentów planowania przestrzennego w kształtowaniu struktury przestrzennej omawianych inwestycji. Przyczyn takiego stanu rzeczy jest wiele. Przede wszystkim spowodowany był on specyfiką działania instrumentów planowania przestrzennego w kształtowaniu przestrzeni dla celów produkcji rolnej. Instrumenty planowe o szerokiej skali przestrzennej (planowanie regionalne), określające kierunki produkcji, zakreślały ogólnie granice terenów produkcji rolnej, ewentualnie - intensywnej produkcji; natomiast plany o małej skali przestrzennej (plany miejscowe, uproszczone plany zagospodarowania przestrzennego gmin) służyły w zasadzie wyznaczaniu terenów budowlanych na obszarach wsi i umożliwiały ochronę gruntów rolnych. Plany zagospodarowania przestrzennego określały zatem produkcyjną przestrzeń rolniczą i na tym kończyło się ich działanie - instrumenty planowania przestrzennego nie działały „wewnątrz” produkcyjnej przestrzeni rolniczej, nie określały sposobu jej rolniczego wykorzystywania. $^{10}$

$7 \quad$ Ustawa z 31.01.1961 r. o terenach budowlanych na obszarach wsi oraz rozporządzenie Przewodniczącego KBUiA z 31.05.1961 r. w sprawie zasad i trybu wyznaczania terenów budowlanych na wsi (Dz.U.Nr 30, poz.150). Por. uchwała Rady Ministrów z 6.04.1974 r. w sprawie opracowania uproszczonych planów zagospodarowania przestrzennego gmin (M.P. nr 15, poz. 95).

10 S. Prutis, Wpływ instrumentów prawnych na przestrzenną strukturę rolnictwa w Polsce, s. 55. 
Celowo, dla charakterystyki doświadczeń empirycznych dotyczących planowania przestrzennego, użyłem formy „wypisów” z ówczesnych wypowiedzi W.Pańki. Chciałem bowiem pokazać, iż znakomicie rozróżniał on spojrzenie racjonalisty (pokazującego ratio legis danej regulacji, jej celów i zadań) oraz empirysty, obnażającego słabości i mankamenty w praktyce funkcjonowania mechanizmów planowania przestrzennego $\mathrm{w}$ rolnictwie przed czterdziestu laty.

W badaniach teoretycznych W. Pańko, określając najistotniejsze funkcje planów zagospodarowania przestrzennego jako narzędzi gospodarki przestrzennej, za podstawę uznał: 1) funkcję synchronizacji wszelkich organizacyjno-prawnych środków gospodarki przestrzennej oraz 2) funkcję koordynacji przestrzennej wyrażającą się w treści planów, a dotyczącą zarówno sfery przedmiotowej (tj. koordynacji działań), jak i sfery podmiotowej, a więc organizowania współpracy działających w przestrzeni jednostek i kojarzenia ich interesów. ${ }^{11}$

W badaniach empirycznych Autor wykazał, iż na znacznym obszarze kraju funkcje planowania przestrzennego nie były realizowane $\mathrm{z}$ powodu braku planów miejscowych; w pełnieniu funkcji koordynacyjnej planowanie gospodarcze dominowało nad planowaniem przestrzennym. $\mathrm{Z}$ powodu braku mocy przerobowych instytucji planowania przestrzennego klasyczne instrumenty - plany miejscowe zastępowane były różnego rodzaju substytutami czy surogatami, takimi jak: projekty wyznaczenia terenów budowlanych, czy uproszczone plany zagospodarowania przestrzennego gmin, tworzonych na podstawie ustawy z 1972 roku. ${ }^{12}$

Odnosząc ówczesne mechanizmy planowania do zadań, jakie powinny spełniać w rolnictwie odnotować trzeba, że mechanizmy te spełniały swoją rolę w zakresie organizacji terenów budowlanych na wsi, w mniejszym stopniu chroniły zasoby gruntowe przed ich przeznaczeniem na cele nierolne (dominacja instrumentów planowania gospodarczego), natomiast kształtowanie sposobu zagospodarowania istniejącego rolniczego zasobu gruntowego nie należało do sfery oddziaływania planowania przestrzennego.

\section{Współczesny obraz planowania przestrzennego na obszarach wiejskich}

Być może zaskoczeniem dla Czytelnika niniejszego opracowania będzie konstatacja, że po upływie blisko 40. lat, przy wprowadzeniu zmian w ustroju polityczno-gospodarczym naszego kraju, wejściu w życie nowych regulacji ustawowych w zakresie planowania przestrzennego, realia funkcjonowania mechanizmów pla-

W. Pańko, Własność gruntowa w planowej gospodarce przestrzennej, s. 76. Autor wyróżnił także funkcję informacyjną planów służącą jawności i pewności życia społeczno-gospodarczego.

12 Ustawa z 29.11.1972 r. o utworzeniu gmin i zmianie ustawy o radach narodowych (tekst jedn. Dz.U. z 1973 r. Nr 47, poz. 277 ze zm.). 
nowania przestrzennego w rolnictwie wykazują daleko idące podobieństwa do stanu z okresu badań prowadzonych przez Profesora Waleriana Pańkę.

Fundament normatywny planowania przestrzennego w XXI wieku stanowi ustawa z dnia 27.03.2003 r. o planowaniu i zagospodarowaniu przestrzennym. ${ }^{13}$ Zakres przedmiotowy regulacji określa art. 1, zgodnie z którym: „Ustawa określa: 1) zasady kształtowania polityki przestrzennej przez jednostki samorządu terytorialnego i organy administracji rządowej, 2) zakres i sposoby postępowania w sprawach przeznaczania terenów na określone cele oraz ustalenie zasad ich gospodarowania i zabudowy - przyjmując ład przestrzenny i zrównoważony rozwój za cel tych działań”.

Ład przestrzenny, w rozumieniu ustawy, oznacza takie ukształtowanie przestrzeni, które tworzy harmonijną całość oraz uwzględnia w uporządkowanych relacjach wszelkie uwarunkowania i wymagania funkcjonalne, społeczno-gospodarcze, środowiskowe, kulturowe oraz kompozycyjno-estetyczne. Zrównoważony rozwój, w rozumieniu prawa ochrony środowiska, ${ }^{14}$ to taki rozwój społeczno-gospodarczy, w którym następuje proces integrowania działań politycznych, gospodarczych i społecznych, z zachowaniem równowagi przyrodniczej oraz trwałości podstawowych procesów przyrodniczych, w celu zagwarantowania możliwości zaspokojenia podstawowych potrzeb poszczególnych społeczności lub obywateli zarówno współczesnego pokolenia, jak i przyszłych pokoleń.

Harmonijny i zrównoważony rozwój stanowią cel i podstawę działań w zakresie racjonalnego zagospodarowania przestrzennego, podejmowanych w kształtowaniu i prowadzeniu polityki przestrzennej na terenie gminy. Planowanie przestrzenne w gminie obejmuje 2 etapy:

1) etap sporządzenia studium uwarunkowań i kierunków zagospodarowania przestrzennego; w studium uwzględnia się zasady określone w koncepcji przestrzennego zagospodarowania kraju, ustalenie strategii rozwoju i plan zagospodarowania województwa oraz strategii rozwoju gminy, o ile gmina dysponuje takim opracowaniem; studium sporządza się dla obszaru w granicach administracyjnych gminy; studium nie jest aktem prawa miejscowego (art. 9 ustawy o planowaniu i zagospodarowaniu przestrzennym)

2) etap sporządzania i uchwalania miejscowych planów zagospodarowania przestrzennego; sporządzanie planów jest fakultatywne - plan miejscowy sporządza się obowiązkowo, jeżeli wymagają tego przepisy odrębne (art. 14 ust. 7 ustawy); plan miejscowy jest aktem prawa miejscowego, a postanowienia planu nie mogą naruszać postanowień studium. 
Elementy konstrukcyjne normatywnego modelu planowania przestrzennego zapewniają logiczne powiązanie pomiędzy kolejnymi dokumentami projektującymi zagospodarowanie przestrzeni gminy: 1) strategią rozwoju gminy, 2) studium uwarunkowań i kierunków zagospodarowania przestrzennego oraz 3) miejscowym planem zagospodarowania przestrzennego gminy. Zapewnienie ładu przestrzennego i zrównoważonego rozwoju konkretnej gminy, przy użyciu ww. mechanizmów, jest procesem niezwykle skomplikowanym, czasochłonnym oraz kosztownym, dlatego też zachodzi duża rozbieżność pomiędzy modelem normatywnym a realnymi procesami zagospodarowania przestrzeni danej gminy.

Co się tyczy rolniczej przestrzeni produkcyjnej, regulacja ustawowa, w swym ujęciu modelowym, na pierwszym miejscu stawia ochronę zasobu gruntów rolnych. Wymagania ochrony środowiska, w tym gospodarowania wodami i ochrony gruntów rolnych i leśnych - zgodnie z art. 1 ust. 2 pkt 3 ustawy - w planowaniu i zagospodarowaniu przestrzennym uwzględnia się ,zwłaszcza”, a zatem funkcja ochrony gruntów rolnych należy do głównych celów planowania przestrzennego. W studium określa się „,W szczególności”: obszary, dla których gmina zamierza sporządzić miejscowe plany zagospodarowania przestrzennego, w tym obszary wymagające zmiany przeznaczenia gruntów rolnych i leśnych na cele nierolnicze i nieleśne (art. 10 ust. 2 pkt 9 ustawy). Gdy chodzi o treść planów miejscowych w relacji z ochroną gruntów rolnych pozostają uregulowania dotyczące przeznaczenia terenów oraz linii rozgraniczających tereny o różnym przeznaczeniu, zasad ochrony i kształtowania ładu przestrzennego (art. 15 ust. 2 pkt 1 i 2 ustawy).

W zakresie organizowania terenów budowlanych i zabudowy na obszarach wsi działać mają instrumenty miejscowego planu zagospodarowania przestrzennego, w którym określa się zasady kształtowania zabudowy oraz wská́niki zagospodarowania terenu, szczególnie warunki zagospodarowania terenów oraz ograniczenia w ich użytkowaniu, w tym zakaz zabudowy (art. 15 ust. 2 pkt 6 oraz 9 ustawy).

Natomiast gdy chodzi o trzecie zadanie planowania przestrzennego w rolnictwie, a mianowicie: kształtowanie samego sposobu zagospodarowania rolniczego zasobu gruntowego, to jedynie w studium przewiduje się określanie kierunków i zasad kształtowania rolniczej i leśnej przestrzeni produkcyjnej (art. 10 ust. 2 pkt 9 ustawy).

Aktualny model normatywny planowania przestrzennego poświęca organizacji przestrzeni rolniczej nie mniej uwagi niż regulacja prawna lat 70-tych ubiegłego wieku. Odpowiedź na pytanie, czy jest to model adekwatny do organizowania procesów rozwojowych współczesnego rolnictwa, jest złożona. $Z$ jednej strony, wydaje się, iż pełny model planowania przestrzennego (studium + plan miejscowy) jest aż nazbyt perfekcyjny (a przez to ociężały i kosztowny) dla organizacji produkcyjnej przestrzeni rolniczej. $Z$ drugiej strony, podstawowy strumień środków na rozwój 
rolnictwa po wejściu Polski do Unii Europejskiej kierowany jest, w ramach Programu Rozwoju Obszarów Wiejskich, nie tylko dla rolnictwa, ale powiązany jest z rozwojem całego obszaru wiejskiego jako obszaru wielofunkcyjnego. Ponieważ pojęcie obszaru wiejskiego nie jest równoważne z produkcyjną przestrzenią rolniczą, koncepcja wielofunkcyjnych obszarów wiejskich powinna mieć swój wyraz i odzwierciedlenie $w$ instrumentach i mechanizmach planowania przestrzennego, a tymczasem przepisy ustawy o planowaniu i zagospodarowaniu przestrzennym nie poświęcają problematyce obszarów wiejskich szczególnego zainteresowania. ${ }^{15}$

Dla przybliżenia odpowiedzi na postawiony dylemat przydatne będą konstatacje dotyczące praktyki z zakresu planowania przestrzennego, będące także konsekwencją regulacji prawnych wykraczających poza unormowania ustawy o planowaniu i zagospodarowaniu przestrzennym.

System planów zagospodarowania przestrzennego przewidziany ustawą o planowaniu i zagospodarowaniu przestrzennym uznać trzeba - w założeniu ustawodawcy - za podstawę, swoisty „ruszt” dla działań gospodarowania przestrzenią w różnej skali i zróżnicowanym horyzoncie czasowym. Nie należy wszakże idealizować systemu planowania przestrzennego w tym sensie, że wszelkie problemy zagospodarowania przestrzeni zostaną rozwiązane i załatwione dopiero $\mathrm{z}$ momentem pokrycia terenu całego kraju siatką planów miejscowych. Do takiego stanu droga jest daleka, a i zuniformizowany model miejscowego planu zagospodarowania przestrzennego nie musi być jedynym pomysłem na mechanizmy planowania przestrzennego.

Sam ustawodawca przyjął w ustawie z dnia 27.03.2003 r. zasadę, że obowiązujące w dniu wejścia w życie ustawy miejscowe plany zagospodarowania przestrzennego uchwalone przed dniem 1 stycznia 1995 r. zachowują moc do czasu uchwalenia nowych planów, jednak nie dłużej niż do dnia 31 grudnia 2003 r. (art. 87 ust. 3 ustawy). Spowodowało to wyeliminowanie z obrotu prawnego wielu aktów planowania przestrzennego. Konieczność sporządzenia studiów gminnych i nowych miejscowych planów zagospodarowania przestrzennego spowodowała, że do chwili obecnej mniej niż połowa obszaru kraju pokryta jest siecią planów miejscowych. Biorąc zaś pod uwagę skomplikowanie, czasochłonność oraz kosztowność sporządzania studiów gminnych oraz miejscowych planów zagospodarowania przestrzennego pogodzić się trzeba z sytuacją, że przez długi jeszcze okres ustawodawca będzie zmuszony posługiwać się surogatami czy substytutami planów. Należy się zatem zastanowić, czy zmiany ustawowe w sferze planowania przestrzennego mogą, i czy powinny prowadzić do utraty mocy obowiązującej aktów prawa miejscowego, jakimi są plany miejscowe. Planowanie miejscowe powinno być procesem ciągłym, stąd zmiany legislacyjne winny, co najwyżej, zobowiązywać gminy do no- 
welizacji planów, a nie do opracowania nowych. Przecież w tych nowych planach i tak musi być uwzględniony stan rzeczywistego zagospodarowania przestrzeni. Za procesem permamentnej nowelizacji planów zagospodarowania przestrzennego przemawia konstytucyjna zasada samodzielności gminy jako jednostki samorządu terytorialnego.

Przy braku planu zagospodarowania przestrzennego dla danego terenu nie mogą, siłą rzeczy, być wypełniane żadne funkcje oddziaływania na wykorzystanie rolniczej przestrzeni produkcyjnej. Przewrotnie wszakże można stwierdzić, iż brak miejscowego planu zagospodarowania przestrzennego jest najlepszym sposobem ochrony gruntów rolnych, albowiem sporządzenie planu miejscowego jest niezbędne dla legalnej zmiany przeznaczenia gruntów rolnych na cele nierolnicze. ${ }^{16}$ Już w studium uwarunkowań i kierunków przestrzennego zagospodarowania gminy określa się obszary, dla których gmina zamierza sporządzić miejscowy plan, w tym obszary wymagające zmiany przeznaczenia gruntów rolnych na cele nierolnicze (art. 10 ust. 2 pkt 9 ustawy o planowaniu i zagospodarowaniu przestrzennym). Zgodnie z art. 14 ust. 3 tej ustawy, plan miejscowy, w wyniku którego następuje zmiana przeznaczenia gruntów rolnych, sporządza się dla całego obszaru wyznaczonego w studium. Zwrot ,sporządza się dla całego obszaru wyznaczonego w studium" oznacza, że jeśli na danym obszarze znajdują się grunty rolne, stanowiące zwarty kompleks nieruchomości gruntowych wymagające zmiany przeznaczenia, to w takim przypadku projekt planu uwzględniający uwarunkowania studium powinien być sporządzony dla całego obszaru (zwartego kompleksu nieruchomości gruntowych) objętego postanowieniami studium. ${ }^{17}$ Dopóki te prace nie zostaną wykonane, zmiana przeznaczenia gruntów rolnych $w$ trybie podstawowym - planowym nie może nastąpić. Zgodnie z art. 4 ust. 1 ustawy, w miejscowym planie zagospodarowania przestrzennego następuje ustalenie przeznaczenia terenu, rozmieszczenie inwestycji celu publicznego oraz określenie sposobów zagospodarowania i warunków zabudowy terenu. W przypadku braku miejscowego planu określenie sposobów zagospodarowania i warunków zabudowy terenu następuje w drodze decyzji o warunkach zabudowy i zagospodarowania terenu, przy czym:

1) lokalizację inwestycji celu publicznego ustala się w drodze decyzji o lokalizacji inwestycji celu publicznego (art. 50-58 ustawy),

2) sposób zagospodarowania terenu i warunki zabudowy dla innych inwestycji ustala się w drodze decyzji o warunkach zabudowy (art. 61-67 ustawy).

Zgodnie z art. 7 ust. 1 ustawy z dnia 3 lutego 1995 r. o ochronie gruntów rolnych i leśnych (tekst jedn. Dz.U. z 2004 r. Nr 121, poz. 1266 ze zm.), przeznaczenie gruntów rolnych i leśnych na cele nierolnicze i nieleśne, wymagające zgody (o której mowa w ust. 2 art. 7 ustawy) dokonuje się w miejscowym planie zagospodarowania przestrzennego, sporządzonym w trybie określonym w przepisach o planowaniu i zagospodarowaniu przestrzennym.

Por. T. Bąkowski, Komentarz do ustawy o planowaniu i zagospodarowaniu przestrzennym, Zakopane 2004, Komentarz do art. 14 
Powyższe decyzje nazywane są potocznie surogatem czy substytutem miejscowego planu zagospodarowania. Trybunał Konstytucyjny zajął wszakże stanowisko, ${ }^{18}$ że decyzja ,nie stanowi substytutu planu miejscowego na obszarze, dla którego plan taki nie został uchwalony [...] przesądza jedynie o rodzaju obiektu budowlanego, który może zostać na danym terenie wybudowany zgodnie z obowiązującymi przepisami prawa planistycznego. W braku planu miejscowego na terenie takim obowiązuje bowiem generalny (ogólny) porządek planistyczny, unormowany wieloma ustawami szczególnymi. Decyzje o warunkach zabudowy nie tworzą per se porządku prawnego i nie mają charakteru konstytutywanego, a - nieco upraszczając - przyjąć można, że stanowią szczegółową informację o tym, jaki obiekt i pod jakimi warunkami inwestor może na danym terenie wybudować bez obrazy przepisów prawa".

Wśród ustawowych warunków zabudowy, określonych w art. 61 ustawy, których łączne spełnienie umożliwia uzyskanie pozytywnej decyzji o warunkach zabudowy główną rolę spełnia wyrażony w art. 61 ust. 1 ustawy warunek dobrego sąsiedztwa. ${ }^{19}$ Od wymogu dobrego sąsiedztwa ustawodawca uczynił wyjątek dotyczący zabudowy zagrodowej. Przez zabudowę zagrodową należy rozumieć w szczególności budynki mieszkalne, budynki gospodarcze lub inwentarskie w rodzinnych gospodarstwach rolnych, hodowlanych lub ogrodniczych oraz w gospodarstwach leśnych. ${ }^{20}$ Odstępstwo od wymogu dobrego sąsiedztwa w zabudowie zagrodowej znajduje zastosowanie w przypadku, gdy powierzchnia gospodarstwa rolnego związanego z tą zabudową przekracza średnią powierzchnię gospodarstwa rolnego w danej gminie (art. 61 ust. 4 ustawy). Swobodę w zabudowie zagrodowej mają zatem lokalne towarowe gospodarstwa rolne. W przypadku zabudowy zagrodowej, czyli budowy w rodzinnych gospodarstwach rolnych, nie dochodzi do zmiany przeznaczenia gruntów rolnych na cele nierolnicze, albowiem - zgodnie z przepisem art. 2 pkt 3 ustawy o ochronie gruntów rolnych i leśnych - grunty pod wchodzącymi w skład gospodarstw rolnych budynkami mieszkalnymi oraz innymi budynkami i urządzeniami służącymi wyłącznie produkcji rolniczej oraz przetwórstwu rolnospożywczemu są, w rozumieniu ustawy, gruntami rolnymi.

Oprócz dobrego sąsiedztwa, wydanie decyzji o warunkach zabudowy terenu (poza terenami zabudowy zagrodowej) dopuszczalne jest, jeżeli teren nie wymaga uzyskania zgody na zmianę przeznaczenia gruntów rolnych na cele nierolnicze albo jest objęty zgodą uzyskaną przy sporządzeniu miejscowych planów, które utraciły moc na podstawie art. 67 ust. 1 ustawy z dnia 7 lipca 1994 r. o zagospodarowaniu

18 W wyroku z dnia 20 grudnia 2007, sygn. akt $P$ 37/06.

19 Dobre sąsiedztwo ma miejsce wówczas, gdy co najmniej jedna działka sąsiednia, dostępna z tej samej drogi publicznej, jest zabudowana w sposób pozwalający na określenie wymagań dotyczących nowej zabudowy w zakresie kontynuacji funkcji, parametrów, cech i wskaźników kształtowania zabudowy oraz zagospodarowania. 
przestrzennym. ${ }^{21}$ Poszanowanie wcześniejszych ustaleń planistycznych co do zmiany przeznaczenia gruntów rolnych jest zrozumiałe, stanowi bowiem swoistą ochronę praw nabytych. Natomiast na mocy przepisu art. 7 ust. 2 pkt 1 ustawy o ochronie gruntów rolnych i leśnych, ${ }^{22}$ zgody ministra właściwego do spraw rozwoju wsi wymaga przeznaczenia na cele nierolnicze gruntów rolnych stanowiących użytki rolne klas I-III, jeżeli ich zwarty obszar projektowany do takiego przeznaczenia przekracza $0,5 \mathrm{ha}$. A zatem w procesie inwestycyjnym prowadzonym w trybie wydania decyzji o warunkach zabudowy i zagospodarowania terenu trwale chronione są grunty rolne klasy I-III o obszarze przekraczającym 0,5 ha. Grunty ww. klas o obszarze mniejszym niż 0,5 ha oraz grunty rolne pozostałych klas bonitacji gleby nie podlegają ochronie co do zmiany przeznaczenia przy wydawaniu decyzji o warunkach zabudowy.

Istotny wyłom w prawnej ochronie gruntów rolnych wprowadziła ustawa $\mathrm{z}$ dnia 19 grudnia 2008 r. o zmianie ustawy o ochronie gruntów rolnych i leśnych poprzez dodanie art. 5 „,b” w brzmieniu: „Przepisów ustawy nie stosuje się do gruntów rolnych stanowiących użytki rolne położone w granicach administracyjnych miast". ${ }^{23}$ Ratio legis dokonanej zmiany upatrywać należy przede wszystkim w przyspieszeniu procesów inwestycyjnych na obszarach miast poprzez pominięcie potrzeby zmiany przeznaczenia gruntów rolnych na cele nierolnicze oraz wyłączenie gruntów z produkcji rolnej. Pominięcie tych etapów w zmianie przeznaczenia gruntów nie tylko przyspiesza realizację inwestycji, lecz także obniża jej koszty poprzez wyeliminowanie opłat z tytułu wyłączenia gruntów rolnych z produkcji. Skoro jednak ustawodawca zadecydował o rezygnacji z ochrony gruntów rolnych położonych $\mathrm{w}$ granicach administracyjnych miast, to zagadnienie ochrony gruntów rolnych przestało być elementem treści planu zagospodarowania przestrzennego na obszarach miejskich. Wydaje się również, że skutkiem wejścia w życie przepisu art. 5 „,b” ustawy o ochronie gruntów rolnych i leśnych tereny w granicach administracyjnych miast uznać należy za teren, który nie wymaga uzyskania zgody na zmianę przeznaczenia gruntów rolnych na cele nierolnicze w rozumieniu art. 61 ust. 1 pkt 4 ustawy o planowaniu i zagospodarowaniu przestrzennym.

Kolejną cechą charakterystyczną współczesnego ustawodawstwa w zakresie przestrzennego rozmieszczenia inwestycji jest określenie szczegółowych zasad realizacji poszczególnych kategorii inwestycji $\mathrm{w}$ drodze specjalnych regulacji ustawowych (tzw. „specustawy”). Począwszy od 2003 roku wydano już osiem ustaw przewidujących regulacje specjalne. ${ }^{24}$ Ustawy te przewidują szczegółowe zasady realizacji poszczególnych kategorii inwestycji. Realizacja inwestycji następuje na pod-

21 Ustawa ta utraciła moc dnia 11 lipca $2003 \mathrm{r}$.

22 Ustawa z dnia 3 lutego 1995 r. (tekst jedn. Dz.U. z 2004 r. Nr 121, poz. 1256 ze zm.).

23 Dz.U. Nr 237, poz. 1657. Ustawa weszła w życie z dniem 1 stycznia 2009 roku.

24 Szersze omówienie „specustaw” zawiera artykuł G. Dobrowolskiego, Szczególne „substytuty” planowania przestrzennego, zamieszczony w niniejszym tomie „Studia luridica Agraria”. 
stawie decyzji, łączących w sobie postanowienia w zakresie lokalizacji inwestycji, podziału nieruchomości i ich wywłaszczenia oraz pozwolenia na budowę (decyzje zezwalające na realizację inwestycji). Decyzje lokalizacyjne wydawane na podstawie „specustaw” określają szczególny tryb lokalizacji, często z wyłączeniem zasad ogólnych przewidzianych ustawą o planowaniu i zagospodarowaniu przestrzennym, a nawet z wyłączeniem przepisów ustawy o ochronie gruntów rolnych i leśnych.

Najbardziej znaną ,specustawą” jest ustawa z dnia 10 kwietnia 2003 r. o szczególnych zasadach przygotowania i realizacji inwestycji w zakresie dróg publicznych. ${ }^{25}$ Decyzja o zezwoleniu na realizację inwestycji drogowej rozstrzyga w przedmiocie lokalizacji drogi publicznej, jak również stanowi pozwolenie na budowę tego przedsięwzięcia. Na mocy art. 11 ,i” powołanej ustawy, w sprawach dotyczących zezwolenia na realizację inwestycji drogowej nie stosuje się przepisów o planowaniu i zagospodarowaniu przestrzennym, a do gruntów rolnych i leśnych objętych decyzjami o zezwoleniu na realizację inwestycji drogowej nie stosuje przepisów o ochronie gruntów rolnych i leśnych (art. 21 ust. 1 ustawy). Z podobną sytuacją mamy do czynienia w przypadku inwestycji w zakresie lotnisk użytku publicznego; na mocy przepisów ustawy z dnia 12 lutego 2009 r. o szczególnych zasadach przygotowania i realizacji takich inwestycji ${ }^{26}$ uzyskanie zezwolenia na realizację inwestycji w zakresie użytku publicznego jest równoznaczne z uzyskaniem decyzji o warunkach zabudowy i zagospodarowania terenu oraz pozwolenia na budowę (art. 14 ustawy). W sprawach dotyczących decyzji o zezwoleniu na realizację inwestycji w zakresie lotniska publicznego nie stosuje się przepisów ustawy o planowaniu i zagospodarowaniu przestrzennym (art. 19 ust. 1 ustawy), a do gruntów rolnych i leśnych objętych taką decyzją nie stosuje się przepisów ustawy o ochronie gruntów rolnych i leśnych (art. 17 ustawy).

Drogi publiczne oraz lotniska użytku publicznego to kolejne ustawowe wyjątki od zasady ochrony gruntów rolnych, które podważają znaczenie samej zasady, nie tyle w sensie ilościowym, co w sensie jej rangi. Przyzwyczajamy się, iż nacisk potrzeb gospodarczych może stanowić zupełnie naturalne uzasadnienie do odstępstw od zasady. W płaszczyźnie legislacyjnej wszystko jest lege artis, albowiem odstępstwa od reguły ustawowej podejmowane są na podstawie ustawy. Jednakże ocena regulacji prawnej problemów inwestycyjnych za pomocą „,specustaw” nie może być jednoznacznie pozytywna.

Zdaniem G. Dobrowolskiego, w obowiązującym stanie prawnym sprawność procesu inwestycyjnego może zostać zachowana jedynie przy wykorzystaniu zezwoleń wydawanych na podstawie ustaw szczegółowych. Następującej w ten sposób „dekompozycji” systemu planowania przestrzennego i inwestycyjnego opartego 
o przepisy ustawy o planowaniu i zagospodarowaniu przestrzennym oraz ustawy prawo budowlane nie należy oceniać negatywnie. ${ }^{27}$

Przyznać trzeba, że szczególne rozwiązania prawne dotyczące realizacji niektórych inwestycji o charakterze publicznym służą niewątpliwie przyspieszeniu i uproszczeniu procedur wydawania zezwoleń na ich realizację, aby w pełni wykorzystać środki unijne, co leży oczywiście w interesie społecznym, albowiem służy rozwojowi infrastruktury gospodarki narodowej.

Zgłaszając uwagi krytyczne podnieść należy, że działanie za pomocą „specustaw" (także w sytuacjach inwestycji oznaczonych indywidualnie ${ }^{28}$ ) przypomina działania sprzed lat 40-stu, kiedy to podejmowano decyzje o lokalizacji inwestycji bez poszanowania zapisów planów zagospodarowania przestrzennego (dominacja planowania gospodarczego nad przestrzennym). Istnieje również niebezpieczeństwo, że nadmierna „dekompozycja” systemu planowania przestrzennego może doprowadzić do sytuacji, kiedy to ustawa o planowaniu i zagospodarowaniu przestrzennym stanie się szacownym, acz niewydolnym ,zabytkiem prawa”.

„Dekompozycja” systemu planowania przestrzennego obejmuje szeroki wachlarz inwestycji. Oprócz wskazanych już inwestycji drogowych oraz w zakresie lotnisk użytku publicznego, regulacje specjalne dotyczą inwestycji w zakresie budowli przeciwpowodziowych, ${ }^{29}$ inwestycji w zakresie linii kolejowych o znaczeniu państwowym, ${ }^{30}$ lokalizacji regionalnej sieci szerokopasmowej (siecią szerokopasmową jest sieć telekomunikacyjna służąca zapewnieniu szerokopasmowego dostępu do internetu), ${ }^{31}$ inwestycji w zakresie budowy obiektu energetyki jądrowej. ${ }^{32}$

Przechodząc do oceny dostosowania regulacji w zakresie planowania przestrzennego do rozwiązywania problemów przestrzennych naszego rolnictwa stwierdzić należy, iż stan tej regulacji budzi wiele zastrzeżeń. Regulacja nie odpowiada aktualnemu modelowi zarządzania rolnictwem. Od czasu wejścia do Unii Europejskiej, funkcjonują programy rozwoju obszarów wiejskich jako obszarów wielofunkcyjnych. W mechanizmach planowania przestrzennego koncepcja „obszaru wiejskiego" nie znajduje odzwierciedlenia; mechanizmy te operują kategoriami: „,rolniczej i leśnej przestrzeni produkcyjnej”, „Zasobu gruntów rolnych”, „,obszarów wymagających zmiany przeznaczenia gruntów rolnych". W stosunku do obszarów miejskich pojawiło się określenie „gruntów [...] położonych w granicach admini-

G.Dobrowolski, op. cit., s. 198.

Przykładem może być ustawa z dnia 24 kwietnia 2009 r. o inwestycjach w zakresie terminalu regazyfikacyjnego skroplonego gazu ziemnego w Świnoujściu (Dz.U. Nr 84, poz. 700 ze zm.).

Ustawa z dnia 8 lipca 2010 r. o szczególnych zasadach przygotowania do realizacji inwestycji w zakresie budowli przeciwpowodziowych (Dz. U. Nr 143, poz. 963).

Ustawa z dnia 28 marca 2003 r. o transporcie kolejowym (tekst jedn. Dz.U. z 2007 r. Nr 16, poz. 94 ze zm.). Ustawa z dnia 7 maja 2010 r. o wspieraniu rozwoju usług i sieci telekomunikacyjnych (Dz.U. Nr 106, poz. 675). Ustawa z dnia 29 czerwca 2011 r. o przygotowaniu i realizacji inwestycji w zakresie obiektów energetyki jądrowej oraz inwestycji towarzyszących (Dz.U. Nr 135, poz. 789 ze zm.). 
stracyjnych miast”. Obszary wiejskie nie stanowią wyodrębnionej kategorii planistyczno-przestrzennej, być może i z tego względu, że planowaniem przestrzennym zajmują się głównie urbaniści będący specjalistami od zagospodarowania przestrzeni miast.

Rola mechanizmów planowania w kształtowaniu rolniczej przestrzeni produkcyjnej uległa znacznemu osłabieniu. Regulacja ustawowa na pierwszym miejscu, przynajmniej formalnie, stawia ochronę zasobu gruntów rolnych. Ze względu na fakultatywny charakter sporządzania planów, jedynie ze studium uwarunkowań i kierunków zagospodarowania gminy może wynikać obowiązek sporządzenia miejscowego planu m.in. dla obszarów wymagających zmiany przeznaczenia gruntów rolnych na cele rolnicze. W takiej sytuacji miejscowy plan sporządzony jest nie w celu ochrony gruntów rolnych, lecz w celu racjonalnej zmiany przeznaczenia tych gruntów na grunty nierolnicze. W takiej sytuacji, to nie plan miejscowy, lecz brak planu miejscowego i postanowienia przepisu art. 61 ust. 1 pkt 4 ustawy o planowaniu i zagospodarowaniu przestrzennym stanowią barierę przed zmniejszaniem zasobów gruntów rolnych najwyższych klas bonitacyjnych. Można wyrazić ubolewanie, że żaden mechanizm ochronny nie działa w stosunku do gruntów rolnych położonych w granicach administracyjnych miast i na terenach niektórych rodzajów inwestycji celu publicznego.

Aktualnie, sporządzenie miejscowego planu zagospodarowania przestrzennego dotyczącego rolniczej i leśnej przestrzeni produkcyjnej jest rzadkością. W związku z tym należy stwierdzić, że druga funkcja planu, jaką jest określenie zasad kształtowania zabudowy oraz wskaźników zagospodarowania terenu, szczególnych warunków zagospodarowania terenów oraz ograniczenia w ich użytkowaniu (w tym zakazu zabudowy), realizowana jest w nikłym stopniu. Nie stanowi to przeszkody do rozwoju zabudowy zagrodowej w gospodarstwach; może stanowić barierę do rozwoju innego rodzaju zabudowy na obszarach wiejskich.

Końcowy wniosek sformułować można w sposób następujący: Podobnie jak przed 40. laty, ogólny model normatywny planowania przestrzennego nie jest adekwatny do aktualnych potrzeb organizacji rozwoju obszarów wiejskich. Rozbudowany i ociężały proceduralnie miejscowy plan zagospodarowania przestrzennego dobrze służy jako instrument organizujący zagospodarowanie terenów miejskich (w granicach administracyjnych miast). Stosowany do zagospodarowania terenów wiejskich koncentruje się wokół wykorzystania rolniczej przestrzeni produkcyjnej, nie uwzględnia natomiast okoliczności, iż obszary wiejskie to nie tylko obszary produkcji rolnej, ale także obszary wielofunkcyjne, zamieszkiwane przez ludność pracującą poza rolnictwem. Wniosek doktrynalny to postulat, aby rozważyć zasadność wyodrębnienia dwóch kategorii miejscowych planów zagospodarowania przestrzennego: obszarów miejskich i wiejskich. 


\section{SPATIAL PLANNING INSTRUMENTS IN AGRICULTURE} (MODEL ASSUMPTIONS AND REALITY)

Key words: spatial planning, rural development, local spatial plan.

The general normative model of spatial planning is not adequate to the current needs of the organization of rural development. Expanded and procedurally unwieldy local spatial development plan serves well as an instrument of organizing urban development (within the administrative boundaries of cities). Used for rural development focuses on the use of the agricultural production space, notwithstanding the fact that rural areas are not only the areas of agricultural production but also a multifunctional areas, inhabited by people working outside agriculture. The doctrinal proposal is the postulate to consider the legitimacy of separation two categories of local spatial development plans: urban and rural. 